\title{
The Power-Interest Nexus in Responses to Syrian Refugee Arrivals in Lebanon: Tensions and Interactions between the State and the International Community
}

\author{
Clothilde Facon
}

\begin{abstract}
This paper focuses on power dynamics between the Lebanese government and the international community in response to Syrian refugee arrivals in Lebanon as of 2011. Looking at the power-interest nexus to understand the multifaceted aspects of both actors' motivations and bargaining tools, it seeks to map the interactions, tensions and opposing discourses at play. The methodology used is based on a series of in-depth interviews with representatives of the international community, Lebanese officials, and civil society actors. It also includes field visits, analysis of extensive documentation, and examination of scientific literature and media sources. This paper argues that international donor interests, beyond humanitarian concerns, have been infused with foreign policy considerations, aiming to prevent Syrian refugees from migrating towards Europe. Meanwhile, the Lebanese government has been encouraging resettlement, and recently returns, notably by implementing policies targeting Syrian refugees in Lebanon. The article posits that asymmetric patterns have emerged between the international community and the government, with Lebanese authorities capitalizing on the use of "productive power" to increase their bargaining position to request further funding.
\end{abstract}




\section{Introduction}

Lebanon is estimated to host over 1.5 million Syrian refugees, ${ }^{1}$ bringing Lebanon's current total population including refugees to 5.5 million - the largest refugee population per capita in the world. ${ }^{2}$ Faced with mass arrivals, Lebanon's migration legislation - which dates back to the 1960 s - remains insufficient. ${ }^{3}$ Lebanon has not signed the primary human right instruments of international refugee law, such as the 1951 Refugee Convention on the status of refugees and its 1967 Protocol. Nonetheless, when the Syrian crisis began in 2011, Lebanese authorities initially maintained an "open door" policy, which allowed a significant number of Syrian arrivals. ${ }^{4}$ However, by the end of 2014, inward migration policies became increasingly restrictive, ${ }^{5}$ limiting legal routes into Lebanon for refugees, as well as their right to work, and international protection.

This study focuses on Lebanon's response to Syrian refugee arrivals as of 2011, including the Lebanese state policies designed to control refugee mobility, and the international community's response to these arrivals. ${ }^{7}$ I draw upon the notion of "governmentality," which has become prominent in research on migration governance. ${ }^{8}$ Governmentality explores the interwoven forms and mechanisms of power and influence in the management of migration flows. ${ }^{9}$ Multi-level governance refers to the "dispersal of state authority and the rise of various interactive regulatory sites." In the field of migration, "it explores the entwining and

\footnotetext{
${ }^{1}$ European Civil Protection and Humanitarian Aid Operations, "Fact Sheet," Website, European Commission, 2020, available at : https://ec.europa.eu/echo/where/middle-east/lebanon en [last accessed 16 March 2020].

2 The country is also home to 180,000 Palestinians and 28,800 Palestinians Refugees from Syria (PRS). See: UNHCR, "Fact Sheet," Website, United Nations High Commissioner for Human Rights, 2019, available at: https://www.unhcr.org/lb/wp-content/uploads/sites/16/2019/03/UNHCR-Lebanon-Operational-Fact-sheet-Februa ry-2019.pdf [last accessed 10 February 2020].

${ }^{3}$ Namely, the 1962 Law Regulating the Entry of Foreigners into Lebanon, their Stay and their Exit from Lebanon; the 1962 Law n 320 on the Control of Entry and Exit from Lebanese border posts; the 1964 By-law $\mathrm{n}^{\circ} 17561$ Regulating the Work of Foreigners in Lebanon and its amendment; and the 1925 Decree $\mathrm{n}^{\circ} 15$ modified by the Law of 11 January, 1960.

${ }^{4}$ Syrians have been migrating to and from Lebanon for long periods of time for seasonal work. In 2011, there were an estimated 300,000 to 600,000 living and working in Lebanon. See: John Chalcraft, The invisible cage: Syrian migrant workers in Lebanon, Stanford, Stanford University Press, 2009.

${ }^{5}$ Lebanon Support, "Formal Informality, Brokering Mechanisms, and Illegality. The impact of the Lebanese State's Policies on Syrian Refugees' Daily Lives”, Beirut, Civil Society Knowledge Centre, 2016, available at: $\mathrm{http} / /$ civilsociety-centre.org/resource/formal-informality-brokering-mechanisms-and-illegality-impact-lebanesestate $\%$ E2\%80\%99s-policies [last accessed 11 February 2020].

${ }^{6}$ Lebanon Support, “Syrian Refugees' Livelihoods. The Impact of Progressively Constrained Legislations and Increased Informality on Syrians' Daily Lives," Beirut, Civil Society Knowledge Centre, 2016, available at: http://civilsociety-centre.org/resource/syrian-refugees-livelihoods-impact-progressively-constrained-legislationsand-increased [last accessed 11 February 2020].

${ }^{7}$ By the international community, I refer to international actors who have enjoyed some degree of influence on the Lebanese response - namely the United Nations and its agencies, especially the United Nations High Commissioner for Refugees (UNHCR), but also main bilateral and multilateral donors. Specific attention will be paid to the European Union (EU) due to its geographical proximity and strategic interest in Lebanon.

${ }^{8}$ Governance can be defined as a process of decision-making involving a variety of actors regarding a public issue, leading to the production of social norms or policies.

${ }_{9}^{9}$ Martin Geiger and Antoine Pécoud, Disciplining the Transnational Mobility of People, London, Palgrave Macmillan, 2013.

${ }^{10}$ Ian Bache and Matthew Flinders, "Conclusions and Implications," in Ian Bache and Matthew Flinders (eds.), Multi-level Governance, Oxford, Oxford University Press, 2004; cited in Tamirace Fakhoury, "Multi-level governance and migration politics in the Arab world: the case of Syria's displacement," Journal of Ethnic and Migration Studies, 2018, p.1310-1326.
} 
blurring of global, regional, and national migration regimes and the multitude of strategies that actors draw upon to manage migration."

This article assesses the adequacy of the power-interest nexus in understanding the interactions, tensions and opposing discourses between the Lebanese government and the international community in the response to Syrian arrivals. In particular, I argue that the Lebanese government first took a passive role by relegating aspects of the response to international actors, but that since 2014, it has sought to regain control. Furthermore, I argue that the response of the international community has aimed to prevent migration of Syrian refugees to Europe.

\section{Power Dynamics between Lebanese Stakeholders and the International Community: A Case Study for Externalisation Policies and North-South Relations}

To study the power dynamics between the Lebanese government and the international community, this article builds upon Barnett and Duvall's multifaceted definition of power ${ }^{12}$ and relies on two conceptual frameworks: the externalisation of EU policies, and the North-South relations. Barnett and Duvall define power as "the production, in and through social relations, of effects that shape the capacities of actors to determine their circumstances and fate." Dahl's notion of "relational power" defines power as the capacity to carry out one's will in a contextual interaction. ${ }^{13}$ According to realist conceptions, power is "the ability of states to use material resources to get others to do what they otherwise would not do." ${ }^{14}$ This focus on hard power and economic resources is shared by neo-Marxists, who argue that state power is determined by modes of production and the extent to which a country is subject to economic exploitation or domination.

Neoliberal institutionalism provides a more nuanced approach, whereby power is based on state interdependence, shared among actors and therefore, less locally concentrated. ${ }^{15}$ This theory also highlights the role of agenda-setting as a tool for securing power, ${ }^{16}$ and of issue-linkage, to describe empowerment through the act of linking separate items that appear on the agenda of the negotiators. ${ }^{17}$ It also emphasises the ideational aspect of power, highlighted by Barnett and Duvall's notion of "productive power" ${ }^{, 18}$ as power acquired through systems of knowledge, social processes, and discursive practices. In this constructivist view, the main factors shaping states' behaviours are shared perceptions.

\footnotetext{
11 Ibid.; Tiziana Caponio and Michael Jones-Corres, "Theorising Migration Policy in Multilevel States: The Multilevel Governance Perspective," Journal of Ethics and Migration Studies, 2017, Vol. 44(12), p. 1-16.

${ }^{12}$ Michael Barnett and Raymond Duvall, op.cit., 2005, p. 42.

${ }_{13}$ Robert Dahl, "The Concept of Power," Systems Research and Behavioral Science, 1957, Vol. 2 (3), p. 201-215.

${ }^{14}$ Michael Barnett and Raymond Duvall, op.cit., 2005, p. 40.

${ }^{15}$ Robert Keohane and Joseph Nye, Power and Interdependence, London, Pearson Editions, 2001.

${ }^{16}$ Paul Light, The President's Agenda: Domestic Policy Choice from Kennedy to Clinton, Baltimore, Johns Hopkins University Press, 1982.

${ }^{17}$ Ernst Haas, "Why Collaborate? Issue-Linkage and International Regimes," World Politics, 1980, Vol. 32 (3), p.357-405.

${ }^{18}$ Michael Barnett and Raymond Duvall, op.cit., 2005.
} 
The "power-interest nexus" stresses the role of interests in shaping power dynamics. National interests refer to a government's goals and aspirations, be it economic, political or military. In realist theory, interests and power are synonymous, as interests are both based on, as well as a condition of power. Yet, from a constructivist point of view, interests are closely linked to ideas and not entirely objective - what matters is how a country perceives the other country's interests. The role of the European Union (EU) in migration management at external borders and beyond has been studied closely within the realm of "securitisation"19 defined as "the process leading to the transformation of certain entities into a threat" and whereby threat images are modelled as the result of discursive processes. Scholars have drawn attention to the "externalities" of migration, ${ }^{20}$ i.e. the impact of the emerging European security discourse and migration policies on decision-making in EU neighbours in North Africa, Eastern Europe, $^{21}$ and Turkey. ${ }^{22}$

Another useful paradigm for this study are North-South power dynamics, whereby Lebanon is considered a "developing" country and the international community is mostly represented by "developed" countries. Traditional and Marxist views coincide in perceiving the North as enjoying more negotiating power to control the South due to its structural superiority. ${ }^{23}$ This perspective is also emphasised by Gramscian hegemony, whereby actors are not fully aware that decisions are determined by structures. ${ }^{24}$ Therefore, North-South cooperation on migration governance would result in migrant sending countries (usually described as "weak") being forced to act against their interest by migrant receiving countries (usually referred to as "strong"). A more nuanced approach of asymmetrical interdependence has highlighted the negotiating power that migration governance offers to the South. In particular, Cassarino ${ }^{25}$ has shown that sending countries are able to capitalise on their participation in collaborative efforts on migration to exert more leverage on the EU, a claim supported by Cuttitta ${ }^{26}$ and Paoletti ${ }^{27}$ with regards to the cooperation between Italy and North African countries.

Existing literature has focused on power dynamics between Lebanon and the United Nations

19 Thierry Balzacq, "The Policy Tools of Securitization: Information Exchange, EU Foreign and Interior Policies," Journal of Common Market Studies, 2008, Vol. 46 (1), p. 75-100.

${ }^{20}$ The externalisation of EU borders is the EU's attempt to project its territorial borders into surrounding countries by exporting its migration policies.

${ }^{21}$ Sandra Lavenex, "EU enlargement and the challenge of policy transfer: The case of refugee policy," Journal of Ethnic and Migration Studies, 2002, Vol. 28 (4), p. 701-72; Malcolm Anderson and Eberhard Bort, Frontiers of the European Union, London, Palgrave Macmillan, 2001.

${ }^{22}$ Shoshana Fine, "Bordering subjects, souls and states: an enquiry into "bordercratic" practices and rationalities in Turkey," Doctoral Dissertation, Paris, Sciences Po, 2016.

${ }^{23}$ Michael Barnett and Raymond Duvall, op.cit., 2005.

${ }^{24}$ Steven Lukes, Power: A Radical View, London, MacMillan Press, 1974.

${ }^{25}$ Jean-Pierre Cassarino, "Migration and Border Management in the Euro-Mediterranean Area: Heading towards New Forms of Interconnectedness," IeMed Yearly Book, 2005, p. 227-231.

${ }^{26}$ Paolo Cuttitta, "The case of the Italian Southern sea borders: cooperation across the Mediterranean?" in Gemma Pinyol (ed.), Immigration flows and the management of the EU's southern maritime border, Barcelona, Cidob Edicions, 2008, p. 45-62.

${ }^{27}$ Emmanuella Paoletti, Migration of Power and North-South Relations: The Case of Italy and Libya, London, Palgrave Macmillan, 2011. 
High Commissioner for Refugees (UNHCR). Kagan ${ }^{28}$ argues that the UNHCR played the role of a "surrogate state," and more recent research has emphasised how the Lebanese government improved its positioning vis-à-vis UN agencies. ${ }^{29}$

This study will build on this literature to highlight new power dynamics, by focusing on interdependencies between the Lebanese state and a group of international actors. ${ }^{30}$ In doing so, this paper makes an original contribution due to the specificities of the Lebanese case, as a case of border policy externalisation in the relatively unexplored Eastern Mediterranean. Lebanon does not border Europe and is not accessible by direct overland route, but it is included in the European Neighbourhood Policy (ENP). Crucially, contrary to most aforementioned examples, migrant flows from Lebanon do not represent an immediate "threat" for the international community, and especially to Europe. ${ }^{31}$ Nonetheless, Lebanon has been the focus of international attention, being an epicentre of the Syrian crisis and witnessing chronic instability. Therefore, this study analyses "symbolic power" as a bargaining chip that potentially challenges structural inequalities.

This paper follows various aspects of Lebanese responses to Syrian migration as well as the power struggles underpinning these aspects. The first section focuses on the responses of the Lebanese government and the international community to Syrian arrivals. The second section examines employment and education responses by Lebanese authorities and the international donor community. The last section explores tensions between the government and the international community regarding the contentious topic of refugee returns to Syria. Throughout, I assess whether the presence of refugees conferred bargaining power to any negotiating party and to what extent this was used to influence other actors.

This paper is based on desk and field research. Fieldwork conducted between August 2018 and January 2019 consisted of 31 directive and semi-directive interviews with members of the international community (UNHCR, IOM, embassies and international non-governmental organisations (INGOs)), the Lebanese government and security entities in Lebanon (including the General Security Office (GSO) and Customs, present at the borders), local non-governmental organisations (NGOs), members of the Lebanese and Syrian civil societies, and Syrian refugees. I also conducted field observations, some of which were compiled during my experience as a volunteer within a Lebanese NGO operating in the Bekaa valley. By scrutinizing the actors' discourses and practices involved in creating policies, I analyse the interactions and power dynamics between them. In doing so, I aim to show that migration

\footnotetext{
${ }^{28}$ Michael Kagan, "We live in a country of UNHCR: The UN surrogate state and refugee policy in the Middle East," Geneva, United Nations High Commissioner for Human Rights, 2011, available at: https://www.unhcr.org/research/working/4d5a8cde9/live-country-unhcr-un-surrogate-state-refugee-policy-middl e-east-michael.html [last accessed 10 February 2020].

${ }^{29}$ Carmen Geha and Joumana Talhouk, "From Recipients of Aid to Shapers of Policies: Conceptualizing Government - United Nations Relations during the Syrian Refugee Crisis in Lebanon," Journal of Refugee Studies, 2018, Vol. 32(4), p.645-663.

${ }^{30}$ See footnote 7.

${ }^{31}$ UNHCR, "Fifth Regional Survey on Syrian refugees' perceptions and intentions on return to Syria, Egypt, Iraq, Lebanon, Jordan," Website, Relief Web, March 2019, available at: https://reliefweb.int/report/turkey/fifth-regional-survey-syrian-refugees-perceptions-and-intentions-return-syria-r pis [last accessed 10 February 2020].
} 
governance in Lebanon is the result of a social and confrontational process of negotiation.

\section{Responses to Syrian Refugee Arrivals: Between Foreign Policy Objectives and Increasingly Restrictive Entry and Regulations for Syrian residency}

This section examines responses to Syrian arrivals and assesses interests and power dynamics between the government and international actors. By "responses," I refer to policies designed by the Lebanese government and UNHCR. The term also includes humanitarian assistance from INGOs and NGOs that have neither the authority to determine refugee status (like the UNHCR) nor the authority to grant access to territories.

\section{International Community Dominance followed by Increased Governmental Control}

Initially, Lebanese authorities took on a relatively passive role in crafting policy responses to Syrian arrivals starting in 2011. They retained the existing open border policy between Lebanon and Syria, implemented through bilateral agreements since the 1990s, under which Syrians could freely travel to and work in Lebanon. Similarly, the "non-encampment policy," whereby the Lebanese government has consistently opposed the establishment of formal refugee camps run by the UNHCR, illustrates a rather passive approach.

The government delegated a large part of the responsibility for the response to the international community, which responded in three main ways. Firstly, since 2013 the Lebanese government received donor contributions ${ }^{32}$ of 6.39 billion USD in support of the crisis, including 4.5 billion USD under the 2017-2020 Lebanon Crisis Response Plan (LCRP). This amount was sent for humanitarian assistance and development aid in order to prevent further deterioration of living conditions for the most vulnerable populations.

Secondly, the UNHCR led the coordination with the Ministry of Social Affairs (MoSA) and was responsible for registering Syrian refugees to facilitate the delivery of aid. ${ }^{33}$ The UNHCR has been active in Lebanon since 1963, but formalising its presence has proven challenging. Since the 2003 Memorandum of Understanding (MoU) between the UNHCR and GSO, which resulted from the arrival of Iraqi refugees, the agency has functioned in a legal limbo regarding refugee protection, as it was tasked with refugee registration, but not legally mandated to provide legal status. ${ }^{34}$ As a result, the UNHCR's mandate has remained largely undefined and has "arguably become increasingly exposed to governmental interference in its operations." ${ }^{35}$ Overall, the UNHCR's relations with the government have

\footnotetext{
${ }^{32}$ The top funding contributors are the United States (US), Kuwait, UNICEF, the World Food Program (WFP), European Civil Protection and Humanitarian Aid Operations (ECHO) and Danish Refugee Council (DRC). Important bilateral donors include Australia, Canada, Denmark, France, Germany, Italy, Kuwait, the Netherlands, Norway, Russia, Saudi Arabia, Sweden, Switzerland, the UAE, the UK, and the US. In total, since 2011, the European Commission and EU countries have allocated more than 1.8 billion USD to Lebanon.

${ }^{33}$ Registered refugees receive a UNHCR certificate which entitles them to international protection.

34 Amreesha Jagarnathsingh, "Lebanon - Country Report: Legal and Policy Framework of Migration Governance," Working paper series 1, RESPOND: Multilevel Governance of Mass Migration in Europe and Beyond, Horizon 2020 (European Union), Civil Society Knowledge Centre, 2018, p.22, available at: https://civilsociety-centre.org/resource/legal-and-policy-framework-migration-governance [last accessed 10 March 2020].

${ }^{35}$ Ibid., p.411.
} 
been beset by tensions since the arrival of Iraqi refugees. ${ }^{36}$ Its growing influence in Lebanon has not resulted in policy changes, ${ }^{37}$ which is in line with its mandate to support - and not oppose - the host government.

Finally, foreign aid occurred alongside increased border management support from Europe (notably France and the UK) and the USA. In particular, the EU-funded "Integrated Border Management" project, implemented by the International Centre for Migration Policy Development (ICMPD) ${ }^{38}$ since 2012, aimed to address significant gaps in the Lebanese security system. ${ }^{39}$ This follows a trend of increasing securitisation of migration policy in Europe, which has been captured by studies focusing on discourses, ${ }^{40}$ and social structures. ${ }^{41}$

The end of 2014 marked a turning point in the Lebanese government's response, as it took a more active role and began restricting Syrian arrivals. Several factors influenced this change. Firstly, the number of UNHCR-registered refugees had reached 1.2 million - a symbolic 25\% population increase stressed by the UNHCR at the time. ${ }^{42}$ Secondly, the northern Bekaa valley came under attack from the then-Islamic State in Iraq and Syria (ISIS) and Jabhat Al-Nusra (JAN), Al-Qaeda's affiliate in Syria, which killed dozens of Lebanese soldiers. Increasing tensions between refugees and host communities, as well as several security crackdowns led to depictions of Syrian refugees as an "existential threat," government to limit arrivals.

By October 2014, government policies included measures to halt the Syrian refugee inflow at the borders, encouraging Syrian nationals to return to Syria, and attempting to formalise and monitor the presence of Syrian refugees in Lebanon to ease the burden on Lebanon's "economy, infrastructure, and to ensure security." 44 This resulted in increasingly restrictive regulations for Syrian residency in Lebanon as of January 2015. The ministerial cabinet also requested from the UNHCR to stop registering refugees from Syria as of May 2015. In this context, the government's initial lax approach seemed to have been replaced by increased control and strategic decision-making.

\footnotetext{
${ }^{36}$ In 2005, UNHCR declared a temporary protection regime for Iraqi refugees that was implemented without any agreement by the state.

${ }^{37}$ Maja Janmyr, "UNHCR and the Syrian refugee response: negotiating status and registration in Lebanon," The International Journal of Human Rights, 2017, Vol. 2 (3), p. 393-419.

${ }^{38}$ The ICMPD receives most of its funding from the EU and the UN.

${ }^{39}$ Interview with a representative of ICMPD Lebanon, Beirut, 11 November 2018. Most of the project's efforts focused on the land border with Syria as well as improving Beirut airport and port of Tripoli security.

Nonetheless, Tholens argued that the IBM project has failed to gain engagement on the political level; see:

Simone Tholens, "Border management in an era of 'state building lite': security assistance and Lebanon's hybrid sovereignty," International Affairs, 2017, Vol. 93(4), p. 865-882.

${ }^{40}$ Barry Buzan, Ole Waever, Morten Kelstrup, and Pierre Lemaitre, Identity, Migration and the New Security Agenda in Europe, New York, St. Martin Press, 1993.

${ }^{41}$ Didier Bigo, "Sécurité et immigration: vers une gouvernementalité par l'inquiétude ?" Cultures \& Conflits, 1998, p. 31-32.

${ }^{42}$ Dima El-Khouri, "Negotiating space: Cities in Lebanon and the challenge of the Syrian refugee influx (2011-2018): the cases of Tebbeneh, el-Nab'a, and the Bourj el-Barajneh Palestinian refugee camp," Doctoral Dissertation - Social Geography, Université de Caen, 2019.

${ }^{43}$ As explained in p. 8-9.

${ }^{44}$ Lebanon Support, "Formal Informality, Brokering Mechanisms, and Illegality. The impact of the Lebanese State's Policies on Syrian Refugees' Daily Lives”, op.cit., p. 9.
} 
To understand the complex power dynamics underpinning this change, we must understand the multifaceted nature of the explicit and hidden interests of both the Lebanese government and the international community.

\section{A Securitised Narrative Shaping EU Foreign Policy}

Foreign donors' explicit interests in contributing to the Syrian refugee crisis are largely humanitarian. ${ }^{45}$ However, a securitised position towards migration also underpins the international community's response. Migration is a primary issue in the EU-Lebanon agenda, justified on security grounds. In November 2015, European Neighbourhood Policy documents focused primarily on terrorist threats and migration. ${ }^{46}$ The EU's strategic interest in cooperating with Lebanon fulfils the objective of preventing Syrian refugees from leaving the country and moving toward Europe.

Indeed, according to an official from the Directorate-General for European Civil Protection and Humanitarian Aid Operations $(\mathrm{ECHO})^{47}$ based in Lebanon, the budget of the ECHO office in Beirut doubled the day after the dead body of Syrian boy Alan Kurdi was found on a Turkish beach and made headlines around the globe. ${ }^{48}$ The ICMPD key expert said that "Lebanon is doing a good job at stopping undesirables from getting to Europe." It is not clear whether "undesirables" refer to refugees, potential terrorists, or to returning foreign fighters. In the same way, a UNHCR employee argued that the reason behind international support for the Lebanese army "in the fight against ISIS terrorists" (and "to ultimately prevent mass migration to Europe") was the same that triggered "Italy to pay the Libyan army to stop the migration." 9

However, the "fear of Syrian refugees leaving for Europe" lacks sound empirical grounding: even though many have gone to Europe, most of the Syrian refugees present in Lebanon want to go back to Syria eventually. ${ }^{50}$ There is even less evidence linking their presence to international security threats. Here, we see the relevance of the "productive power" concept in referring to "the constitution of all social subjects with various social powers through systems of knowledge and discursive practices of broad and general social scope. ${ }^{51}$ Assigning meaning through defining Syrian migrants as a threat prevails in shaping Europe's interests. The use of the interviewee's term "undesirable" - a pejorative term conflating terrorists and refugees - epitomises this discursive process.

\footnotetext{
${ }^{45}$ See Co-Chair's Declaration of the Brussels III conference held in March 2019: "Brussels III renewed and strengthened the political, humanitarian and financial commitment of the international community to support the Syrian people, the neighbouring countries and the communities most affected by the conflict."

${ }^{46}$ The fund to support Syria neighbours in hosting refugees was supplemented by projects to tackle illegal migration. See: European Commission, "Joint communication to the European Parliament, the Council, the European Economic and Social Committee and the Committee of the Regions - Review of the European Neighbourhood Policy," Website, European Commission, 18 November 2015, available at: https://eur-lex.europa.eu/legal-content/en/TXT/?uri=celex:52015JC0050 [last accessed 10 February 2020].

${ }^{47} \mathrm{ECHO}$ is the European Commission's department for overseas humanitarian aid and civil protection.

${ }^{48}$ Interview by the author with an ECHO officer, Beirut, 18 September 2018.

${ }^{49}$ Interview with a UNHCR officer, Zahle, 13 December 2018.

${ }^{50}$ UNHCR, op.cit., 2019.

${ }^{51}$ Michael Barnett and Raymond Duvall, op.cit., 2005, p. 55.
} 
The EU's humanitarian support at times converges with its foreign policy objectives. Resettlement to third countries is one of three long-term solutions to displacement offered by the UNHCR. Yet since 2011, around 3,5\% of the total number of Syrian refugees present in Lebanon have been resettled..$^{52}$ The procedure is supposed to follow "vulnerability" criteria put forth by the UNHCR. ${ }^{53}$ Nonetheless, the top-down reality of resettlement has been revealed in literature showing that in fact, most states assert their own separate criteria. ${ }^{54}$ Interviews with UNHCR resettlement officers, NGO workers and other humanitarian actors witnessing the process suggest that this is also the case in Lebanon. Resettlement countries have specified other criteria, such as selecting certain sects. A former UNHCR resettlement assistant maintained that: "sometimes, they say 'we only want religious minorities' (...) They assume that Christians are more open [minded], more educated, and that they will integrate in Europe better."

Another UNHCR employee said "Australia said they wanted Iraqis minorities that were impacted by ISIS." ${ }^{56}$ This illustrates the tendency to seek a "victim image" of foreigners that Westerners would be more likely to identify with, i.e. someone who is not Muslim, or someone impacted by Islamist terrorist groups rather than by the Syrian regime. However, from 2015 on, refugees whose history includes life in territories surrendered to terrorist groups have been screened out - resettlement interviews having been increasingly infused with security concerns due to the terrorist threat in Europe. A former UNHCR resettlement assistant explains: "before [2015], if a person had lived under ISIS, that was not a big deal. However, now they believe that those people could be hidden terrorists themselves, persons who have been brainwashed., ${ }^{, 5}$

These examples also show the relevance of the notion of "productive power," as they epitomise how subjects are discursively produced, with categories such as "Muslim," "terrorist," "vulnerable population," etc. These discriminatory practices, which go against the UNHCR's protection mandate, support the idea that Western states have adopted a securitised position towards migration and use the UNHCR to prevent refugee arrivals.

\section{Lebanon's Interest in Limiting Syrian Refugee Arrivals}

Since the beginning of Syrian arrivals, the Lebanese government's primary goal has been to ensure that the Syrians' stay would only be temporary, until their resettlement or return to Syria. ${ }^{58}$ Their integration has never been an option, especially as it is believed to alter the

\footnotetext{
522014 saw the first increase in resettlement, with 4,903 resettled Syrian refugees. In 2015, 7,109 Syrians were resettled; 24,426 in 2016. As of then, the figures kept decreasing: 12,617 in 2017 and 9,805 in 2018. The largest resettlement countries are Canada, the UK, Norway, Germany, France and Sweden.

${ }^{53}$ For example, legal and/or physical protection needs, survival of violence and/or torture, lack of foreseeable alternative durable solutions, woman and girls at risk, children and adolescents at risks, medical needs and family reunification.

54 Annelisa Lindsay, "Surge and Selection: Power in the Refugee Resettlement Regime," Forced Migration Review, 2017, issue 54, p.11-12.

${ }^{55}$ Interview with a former UNHCR resettlement assistant, Beirut, 27 November 2018.

${ }^{56}$ Interview with a UNHCR resettlement assistant, Zahlé, 30 October 2018.

${ }^{57}$ Interview with a former UNHCR resettlement assistant, Beirut, 27 November 2018.

${ }^{58}$ The $2003 \mathrm{MoU}$ states that resettlement is the long-term solution advocated by Lebanese authorities.
} 
delicate power balance between Lebanon's biggest sects. ${ }^{59}$ By 2014, the Lebanese government also started to adopt a securitised narrative, shaped by clashes between rebel fighters and the Lebanese army. "In a span of a year [...] refugees went from being the symbol of resistance to Bashar al Assad and the Syrian revolution to a national threat in Lebanon, reminiscent of the presence of the Palestinian refugees." An official from ECHO, based in Beirut, compared the way in which local and international actors adopted a securitised vision of Syrian refugees: "from one day to the other, Syrians were depicted as an 'existential threat' for civilians. This is the same terminology that the EU has been using." ${ }^{61}$ This quote also epitomises the relevance of "productive power" in shaping Lebanon's interests: by conferring the social identity of "existential threat" to the "other," the Lebanese government and the EU bestow upon themselves the right to conceive and adopt whatever measures so as to avoid this "threat."

Therefore, the October 2014 policy changes aimed to halt Syrian arrivals at the border and formalise and control the presence of those already living in Lebanon. In conversations, Lebanese officials and civil society actors agreed that the government was preoccupied with the idea of "appearance" of state control, as the effectiveness of such measures was questionable. Actors operating in the Bekaa valley suggested that Syrians who could no longer enter Lebanon through legal crossing points increasingly resorted to smugglers, illegally crossing in the north of the Bekaa, in mountainous and dangerous areas. ${ }^{62}$

The decision by the Council of Ministers to stop registering Syrian refugees in order for official numbers to decrease, also seemed to be about controlling appearances. The director of a Lebanese NGO claimed that "it was a political decision." ${ }^{63}$ A representative of the Ministry of State for Displaced Affairs elaborated

"Indeed, we started noticing the numbers decreasing; but this was mainly due to the fact that many of the 1.5 million were legally resettled, or that they fled illegally by the sea during the 2015-2016 influx ... Others returned to Syria. Still, for the government of Lebanon towards its public, the number has decreased, and it was a successful policy." 64

Nonetheless, the goal of "halting the refugee inflow at the border" seemed to prove effective to some extent. ${ }^{65}$ The "process of formalizing and controlling [the] Syrian presence" had the opposite effect: "the absence of legal status, limited possibilities to comply with the

\footnotetext{
59 The 1943 National Pact allocated political power in a confessional system based on the 1932 census. This power balance underwent minor changes with the Taif Agreement in 1990 in favour of the Muslim communities. ${ }^{60}$ In Lebanon, Palestinian camps represent extra-territorial sites of armed resistance, See: Dima El-Khouri, op.cit., 2019, p. 141.

${ }^{61}$ Interview with an ECHO officer, Beirut, 18 September 2018.

${ }^{62} \mathrm{Al}$ Jazeera, "Refugees found frozen in Lebanon near Syria border", Website, Al Jazeera News, 19 January 2018 , available

at: https://www.aljazeera.com/news/2018/01/refugees-frozen-lebanon-syria-border-180119180011632.htm [last accessed 10 February 2020].

${ }^{63}$ Interview with the director of a human rights NGO, Beirut, 26 December 2018.

${ }^{64}$ Interview with a representative of the Ministry of State for Displaced Affairs, Beirut, 30 November 2018.

${ }^{65}$ In the first quarter of 2015, the UNHCR reported a 75\% drop in Syrian refugee registrations, compared to the same period in 2014. See: Lebanon Support, "Formal Informality, Brokering Mechanisms, and Illegality. The impact of the Lebanese State's Policies on Syrian Refugees' Daily Lives," op.cit., p.28.
} 
requirements for the new entry categories, the lack of clarity in the renewal procedures, and the high costs involved" led to a "continuation, and even expansion, of illegal structures.", This understanding of actors' ulterior motives in responding to Syrian arrivals allows us to observe the evolution of the power dynamic underpinning their cooperation.

\section{An Evolving Power Dynamic Benefitting Lebanese Authorities}

According to a representative of Lebanon's Ministry of Foreign Affairs (MoFA), at the beginning of the Syrian crisis, the government was pressured by the international community to keep its borders open. ${ }^{67}$ However, a few years later, Lebanese authorities requested from UNHCR to stop registration. The UNHCR could still "record" Syrians as "persons of concern," assistance. Yet, it could not issue a certificate, which had become essential for residency in Lebanon. This decision led to a power shift, giving the government more authority on who could get what kind of protection and significantly reduced the agency's capacity for action.

Lebanon has two main bargaining chips with the international community. Firstly, it appeals to state sovereignty. The UNHCR's mandate is to support host governments ${ }^{69}$ and therefore it cannot openly oppose them. Secondly, it relies on Europe's securitised position towards migration. If migration governance was not considered a major concern for the EU, Lebanon would be deprived of a critical lever. The Lebanese government uses "productive power" for its own gain, drawing on fears generated by the idea of Syrian arrivals in the European imaginary - not actual arrivals - to assume a stronger position during negotiations. This reveals the interactive dimension of power.

Crucial to appraising power dynamics are each actors' reciprocal expectations. Indeed, the perception that Europe wants to keep refugees at bay is shared among the Lebanese public. ${ }^{70}$ A retired General from the GSO argued that:

"It is in the interest of the international community that Lebanon remains stable. Because they don't want that [...] all Syrians and Palestinians and everyone find a way to leave for Europe. So this is what maintains Lebanon's stability [...]. Europeans have a vested interest in reinforcing service capacities, at ports, at border posts, because it can limit departures, detect fake passports." ${ }^{, 1}$

\footnotetext{
${ }^{66}$ Ibid.

${ }^{67}$ Interview with a representative of the MFA, Beirut, 11 December 2018.

${ }^{68}$ Lebanon Support, "Access to Healthcare for Syrian Refugees. The Impact of Fragmented Service Provision on Syrians' Daily Lives," Beirut, Civil Society Knowledge Centre, 2016, p.7, available at: https://civilsociety-centre.org/sites/default/files/resources/accesshealthcaresyrianrefugees-ls2016.pdf $\quad$ [last accessed 10 February 2020].

${ }^{69}$ UNHCR, "Emergency Handbook," Website, United Nations High Commissioner for Refugees, 2015, p.1, available at: https://emergency.unhcr.org/entry/78614/working-with-a-host-government [last accessed 10 February 2020].

70 "There is a common perception among Lebanese political actors that it is in the international community's interest to maintain stability and good living conditions for the Syrian refugees in Lebanon to avoid more refugees fleeing to Europe", in Sami Atallah and Dima Mahdi, "Law and Politics of 'Safe Zones' and Forced Return to Syria: Refugee Politics in Lebanon,” Beirut, Lebanon Centre for Policy Studies, October 2017, p.16, available at: https://www.lcps-lebanon.org/publications/1515749841-lcps report - online.pdf [last accessed 10 February 2020].

${ }^{71}$ Interview with a retired General from GSO, Beirut, 29 November 2018.
} 
It is just as important that Lebanese actors assume that the EU and other donors gain strong presence in Lebanon because of perceived "security threats" linked to immigration. In that sense, anticipating such a (shared) perception of fear can shape power dynamics. The interaction between donors and local actors was progressively shaped by how the latter conceive the interest of the former. As such, local actors consider that adjusting to their interlocutors' language would give them more leverage. According to a representative of a Lebanese NGO, Lebanon is able to leverage certain powers to raise alarm about migration flows and pressure Europe to obtain concessions:

"Deals between smugglers and Lebanese maritime forces can increase, in a way for Lebanon to have more leverage with the EU. To make yourself relevant on the map of Europe, create a crisis for them. Start sending more boats... Ultimately, this would put the Lebanese authorities on the map of FRONTEX. So Lebanon [could] become something relevant so we can make a deal like with Libya, Tunisia, Morocco, Turkey.”

This quote epitomises how a discursive image produced by the EU becomes a power asset for Lebanon. Furthermore, the protracted nature of the Syrian conflict has weakened the bargaining position of international actors. As attempts to resolve the conflict have failed, the Lebanese authorities have strengthened their positioning to request more funding.

Of total donations pledged during the 2018 Brussels II conference on "supporting the future of Syria in its region," $19 \%$ have been dedicated to Lebanon - of which $31 \%$ in concessional loans (296 million USD). ${ }^{73}$ In total, since 2012, the international community has spent 1.5 billion USD in security assistance, most of it in capacity building, training, equipment and financing for the Lebanese Army. ${ }^{74}$ The projects targeting border maintenance, infrastructure and specialised border control equipment, as well as army training enabled control of its borders. $^{75}$

The above illustrates that power, as the "production of subjects through social relations," can be analysed as an interactive process between Lebanese and international actors. It provides an example of how, despite an initial structural imbalance of power (to the disadvantage of Lebanon), migration was used to gain leverage. This challenges traditional views of North-South power dynamics that still consider the Lebanese government as "structurally weak." Through the use of "productive power," the Lebanese government has been increasingly successful in negotiating financial aid, training, and equipment from the international community, which, in return, considers this as an opportunity to externalise EU borders.

\footnotetext{
${ }^{72}$ Interview with the Director of a human rights NGO, Beirut, 26 December 2018.

${ }^{73}$ European Union, "Supporting Syria and the Region: Post-Brussels conference financial tracking," Brussels, Relief Web, March 2019, p.4-6, available at: https://reliefweb.int/sites/reliefweb.int/files/resources/syria-report-seven 0.pdf [last accessed 10 February 2020]. ${ }^{74}$ Security Assistance Monitor, "Security Aid Pivot Table - Programs," Website, Security Assistance Monitor, 2012-2019, available at: http://securityassistance.org/data/program/military/Lebanon [last accessed 10 February 2020].

${ }^{75}$ Interview with a key expert at ICMPD Lebanon, Beirut, 11 November 2018.

${ }^{76}$ Michael Barnett and Raymond Duvall, op.cit., 2005.
} 


\section{Divergence in Goals between Authorities and Foreign Donors Regarding Refugee Employment Versus Congruent Interests in Education Policies}

Donor conferences ${ }^{77}$ have offered Lebanon opportunities for "agenda-setting" as a tool for securing power. $^{78}$ The cooperation between the state and the international donor community revolves around broad issues such as economic growth, security and development. Among these, refugee arrivals have been prioritised in recent years. By establishing connections between refugee arrivals and other issues corresponding to its interests, the government has increased its bargaining power. Here, the concept of "issue-linkage" ${ }^{\text {"79 }}$ is applicable. How does the manner in which issues are linked inform about the overall bargaining dynamics?

Within a North-South paradigm, Lebanon, as the recipient of international aid, is in a structurally "weak" position. Yet, scholars such as Cassarino ${ }^{80}$ have shown that countries recipient of international aid have been capable of capitalizing on their participation in collaborative efforts on migration to exert more leverage on the EU to extract financial aid.

Employment and education are two sectors in which international funding has been relatively important. The government's goal has been to avoid refugee integration while easing the burden on host communities. We will examine in the next section to what extent Lebanon has been able to influence foreign donors in its interests. As these two sectors are potential drivers of refugee integration, they are contentious and touch upon crucial power dynamics.

Syrians have been working in Lebanon long before the eruption of the Syrian conflict, and "it is estimated that two years after [its] outbreak [...], the Syrian workforce in Lebanon increased between $30 \%$ and 50\% [as compared to before the war], comprising about $14 \%$ of Lebanon's total workforce." ${ }^{81}$ Although the Lebanese government had adopted the principle of "preference for nationals," it announces, generally by yearly decrees, exceptions of fields in which Syrians are allowed to work. Currently, Syrian migrant workers who are not recorded with UNHCR, are constrained to work in the sectors of agriculture, construction and "environment". Syrians wishing to work were required to have a "pledge of responsibility" by a Lebanese sponsor from January 2015, and to obtain a legal status as migrant - denying them UNHCR aid. Lebanon Support's report ${ }^{82}$ indicates that these policies, meant to formalise Syrians' presence in the labour market, had the opposite effect. "A lack of legal status," "restricted access to the labour market" and "conflicting policies and practices" have "pushed many Syrians into illegality and informal structures" and resulted in further abuse and exploitation. ${ }^{83}$ The reluctance of Lebanese authorities to formalize the employment of

\footnotetext{
77 In particular, the London conference on "supporting Syria and the region" held in February 2016 and the Brussels I, Brussels II and Brussels III conferences held respectively in March 2017, 2018 and 2019.

${ }^{78}$ Paul Light, op.cit., 1982, p.31.

${ }^{79}$ Ernst Haas, op.cit., 1980.

${ }^{80}$ Jean-Pierre Cassarino, op. cit., 2005.

${ }^{81}$ Lebanon Support, "Syrian Refugees' Livelihoods. The Impact of Progressively Constrained Legislations and Increased Informality on Syrians' Daily Lives," op.cit., p.12. The figures are based on the World Bank Data on the economic and social impact assessment of the Syrian conflict.

${ }^{82}$ Ibid.

${ }^{83}$ Ibid., p.35.
} 
Syrians is justified by their unwillingness to ease Syrians' integration, and by low ability of the Lebanese economy to integrate new formalised work - as local unemployment already reaches $25 \%{ }^{84}$

However, foreign donors have called for host countries to open up their labour markets to support refugee livelihoods. This is in line with calls "for a proper, organised market and job creation - in which Lebanon would benefit from tax money and Syrians would benefit from protection. ${ }^{, 85}$ As a result, in 2016, the Lebanese government announced measures to enhance employment with the creation of 300,000 jobs through the Subsidised Temporary Employment Program (STEP) program; yet details about the project remain unclear. ${ }^{86}$ In addition, during the Brussels conferences, foreign donors committed to support job creation and donor pledges during the CEDRE conference ${ }^{87}$ nearly covered the entire first phase of its "Capital Investment Program" (CIP). Further, through the European External Investment Plan (EIP), in February 2018, the EU announced a package of up to 164 million USD to support the Lebanese economy. Despite disbursing these funds, foreign donor advocacy to formalise refugee employment has proved ineffectual. The few measures aimed at enhancing Syrian work arrangements were in temporary and undesired jobs, precluding the possibility for integration.

Refugee education has also been a key component of the response in Lebanon, with proactive policies designed to provide refugee children with access to public education. Initially, the NGOs took over the responsibility of providing educational opportunities, however, MEHE later "decided to lead the educational response". ${ }^{88}$ The 2014 launch of Reaching All Children with Education (RACE) emphasised the importance of providing education to refugee children, in line with foreign donors' efforts to include Syrian children in Lebanon's public-school system. A representative of the MEHE said that they "wanted to make sure that the situation would not lead to extremism, or to a whole new generation of Syrians who do not have the capacity to rebuild their country. The international community continued to bargain using two mechanisms. The first one is the use of financial incentives. The second mechanism is the use of a "“child-rights lens' rather than a 'refugee-rights lens:" 89 by advocating for Lebanon's legal obligations as a signatory of the United Nations Convention on the Rights of the Child, transnational actors including NGOs attempted to pressure the Lebanese state to comply with Lebanon's international legal obligations to children.

While the Lebanese government benefited from international aid in the labour sector despite diverging interests - in the education sector, it capitalised on converging interests.

\footnotetext{
${ }^{84}$ Refer to data from the Ministry of Labour in Unemployment in Lebanon, findings and recommendations (2019) by the Lebanese Republic Economic and Social Council.

${ }^{85}$ Lebanon Support, "Syrian Refugees' Livelihoods. The Impact of Progressively Constrained Legislations and Increased Informality on Syrians’ Daily Lives,” op.cit., p.36.

${ }^{86}$ Lebanon Support, "Syrian Refugees' Livelihoods. The Impact of Progressively Constrained Legislations and Increased Informality on Syrians' Daily Lives," op.cit..

${ }^{87}$ The Conférence économique pour le développement, les réformes et avec les entreprises (CEDRE) hosted by France on 06 April 2018.

${ }^{88}$ Elizabeth Buckner, Dominique Spencer and Jihae Chae, "Between Policy and Practice: The Education of Syrian Refugees in Lebanon", Journal of Refugee Studies, 2017, Vol. 31(4), p. 444-465.

${ }^{89}$ Ibid., p. 453
} 
The government's ability to implement its agenda within different sectors further demonstrates its leverage over the international community.

Thus, power dynamics between the government and the international community challenge Marxist ideas that the participation of the South in migration control is entirely dictated by the North. This situation could be characterised as mutually beneficial, rather than a zero-sum outcome. This confirms neoliberal approaches to power as an interactive process based on state interdependence. Lebanon has capitalised on collaboration in handling Syrian refugees to exert more leverage on the EU and to extract financial aid. Nonetheless, the protracted nature of the conflict threatens the sustainability of this power balance, redirecting the debate to refugee returns to Syria.

\section{Refugee Returns to Syria see Tensions and Opposing Discourses between the Government and the International Community}

To nuance previous dynamics in the field of employment and education, this section scrutinises ongoing power dynamics regarding returns highlighting divergence between Lebanese and foreign interests. Further contradictions between international actors' stances on the Syrian regime make this topic highly contentious.

As resettlement quotas have decreased throughout the Syrian crisis, Lebanese authorities have simultaneously pushed for refugee return. ${ }^{90}$ Western donors have so far opposed returns, based on the UNHCR's position that security and humanitarian conditions in Syria are not satisfactory. ${ }^{91}$ This imperative is supplemented by international geopolitical motivations; indeed, working with the Syrian regime to support returns would grant it legitimacy and increase Russia's leverage in the region. Therefore, Lebanese authorities' willingness to use foreign resources to organise large-scale returns appears unlikely to succeed, creating further tensions.

Without the support of the international community, Lebanese authorities have relied on domestic actors to facilitate returns. This required distancing itself from a human-rights based approach as primary conditions of safety, voluntariness, and sustainability, are not yet fulfilled. $^{92}$ In May 2019, eight NGOs expressed concern towards recent decisions adopted by the Supreme Defence Council that would lead to the deportation of Syrians ${ }^{93}$ and towards the decision by the General Director of GSO on 13 May 2019 to deport all Syrians who entered

\footnotetext{
${ }^{90}$ During the Arabic Economic and Social Development Summit held in Beirut in January 2019, the President of Lebanon, Michel Aoun encouraged the "safe return of displaced Syrians" and recalled that the process should not be linked to a political solution in Syria.

${ }^{91}$ UNHCR Update on durable solutions for Syrian refugees, June/July 2018.

${ }^{92}$ Ahmet Içduygu and Maissam Nimer, "The politics of return: exploring the future of Syrian refugees in Jordan, Lebanon and Turkey," Third World Quarterly, 2018, Vol. 41(3), p.415-433.

${ }^{93}$ The Legal Agenda, "Position Paper on the decision to summarily deport Syrian nationals who entered Lebanon irregularly," Website, The Legal Agenda, 2019, available at: https://legal-agenda.com/uploads/Position\%20Paper\%20on $\% 20$ the $\% 20$ decision $\% 20$ to $\% 20$ summarily $\% 20$ deport $\% 20$ Syrian $\% 20$ nationals $\% 20$ who $\% 20$ entered $\% 20$ Lebanon $\% 20$ irregularly.pdf [last accessed 10 February 2020].
} 
Lebanon irregularly after April 2019. ${ }^{94}$ Nonetheless, "returns, notably through forcibly signed 'voluntary' forms, are on the rise, although circumventing the principle of non-refoulement." 95

The UNHCR's position has provoked clashes with Gebran Bassil, the Minister of Foreign Affairs, who has publicly accused the UNHCR of having a "hidden agenda" of keeping refugees in Lebanon. ${ }^{96}$ This provoked further tensions when Bassil threatened to stop issuing visas to UNHCR staff. Left with no choice, the UNHCR monitored convoys going back to Syria to provide refugees with medical and legal assistance. According to an ECHO officer, "UNHCR would never have accepted that a few years ago... we went from a situation in which everyone would refuse to sit with Assad, to a situation in which Damascus can use returns as leverage in order to be legitimised by the international community." ${ }^{97}$ This illustrates that the UNHCR has little leverage over the Lebanese government. An interviewee from the civil society perceived the fact that the agency refuses to take a critical stance as problematic. Talking about UN employees under threat of losing visas, he said "you should [be able to] do whatever you want! If you are persona non grata, it is [the government] that is going to be shamed. Can you imagine, a Foreign Affairs ministry making UN people persona non grata!" ${ }^{98}$ Lebanese authorities have made use of their "compulsory power" ${ }^{\text {"99 }}$ to pressure the UNHCR, demonstrating that their willingness to facilitate refugee return exceeded their interest in keeping good relations with the agency. Patterns of asymmetry in dialogue about returns between the UNHCR and the government have worsened, with the latter pressuring the former.

\section{Conclusion}

This paper assessed the power dynamics between Lebanon and the international community in response to the arrivals of Syrian refugees as of 2011. It shows that Lebanese authorities through extra control - have gained leverage which enabled them to extract extra funding, equipment, and aid from the international community, while the international community has pursued the goal of preventing migrant flows to Europe. The Lebanese government has regained control over several aspects of the response. It has managed to capitalise on cooperation with foreign donors in order to redirect funds to serve their own economic interests and, at least in theory, those of the host community, particularly regarding employment and education. These shifts in funding patterns have been accepted by the international community as they pave the way for externalising EU migration control. The results of this research challenge the idea that structural inequality inevitably underpins

\footnotetext{
${ }^{94}$ General Director of the General Security Decision, No. 43830, 13 May 2019.

95 Amreesha Jagarnathsingh, "Lebanon's Border Regime: Fluid Rigidity, Foreign Interference and Hybrid Security Assemblages," Working paper series 2, RESPOND: Multilevel Governance of Mass Migration in Europe and Beyond, Horizon 2020 (European Union), Civil Society Knowledge Centre, 2019, p.45, available at: https://civilsociety-centre.org/resource/lebanon $\% \mathrm{E} 2 \% 80 \% 99 \mathrm{~s}$-border-regime-fluid-rigidity-foreign-interferenceand-hybrid-security-assemblages [last accessed 10 February 2020].

${ }^{96}$ Jeanine Jalkh, "Bassil part en guerre contre le HCR," Website, L'Orient-Le Jour, 09 June 2018, available at https://www.lorientlejour.com/article/1119987/bassil-part-en-guerre-contre-le-hcr.html [last accessed 10 February 2020].

${ }^{97}$ Interview with an ECHO officer, Beirut, 18 September 2018.

${ }^{98}$ Interview with the Director of a human-right NGO, Beirut, 26 December 2018.

99 “As "power as relations of interaction of direct control." See: Michael Barnett and Raymond Duvall, op.cit., 2005 , p. 43.
} 
North-South relations. Analysing the multifaceted relationship dynamics between Lebanon and the international community reveals a complex interplay of gain and losses on both sides, where migration policies have become a form of bargaining power for Lebanon, at least to a certain extent. This finding validates the relevance of productive power (in comparison to structural power's binary relation of domination) as power is here a diffuse social process that concerns the capacity for action for the structurally advantaged and disadvantaged alike.

\section{Bibliography}

Malcolm Anderson and Eberhard Bort, Frontiers of the European Union, London, Palgrave Macmillan, 2001.

Sami Atallah and Dima Mahdi, "Law and Politics of 'Safe Zones' and Forced Return to Syria: Refugee Politics in Lebanon,” Beirut, Lebanon Centre for Policy Studies, October 2017, p.16, available https://www.lcps-lebanon.org/publications/1515749841-lcps_report_-_online.pdf [last accessed 10 February 2020].

Ian Bache and Matthew Flinders, "Conclusions and Implications," in Ian Bache and Matthew Flinders (eds.), Multi-level Governance, Oxford, Oxford University Press, 2004

Thierry Balzacq, "The Policy Tools of Securitization: Information Exchange, EU Foreign and Interior Policies,” Journal of Common Market Studies, 2008, Vol. 46 (1), p. 75-100.

Didier Bigo, "Sécurité et immigration: vers une gouvernementalité par l'inquiétude ?" Cultures \& Conflits, 1998, p. 31-32.

Elizabeth Buckner, Dominique Spencer and Jihae Chae, "Between Policy and Practice: The Education of Syrian Refugees in Lebanon”, Journal of Refugee Studies, 2017, Vol. 31(4), p. $444-465$.

Barry Buzan, Ole Waever, Morten Kelstrup, and Pierre Lemaitre, Identity, Migration and the New Security Agenda in Europe, New York, St. Martin Press, 1993.

Tiziana Caponio and Michael Jones-Corres, "Theorising Migration Policy in Multilevel States: The Multilevel Governance Perspective," Journal of Ethics and Migration Studies, 2017, Vol. 44(12), p. 1-16.

Jean-Pierre Cassarino, "Migration and Border Management in the Euro-Mediterranean Area: Heading towards New Forms of Interconnectedness," IeMed Yearly Book, 2005, p. 227-231.

John Chalcraft, The invisible cage: Syrian migrant workers in Lebanon, Stanford, Stanford University Press, 2009.

European Civil Protection and Humanitarian Aid Operations, "Fact Sheet," Website, European Commission, 2020, available at: https://ec.europa.eu/echo/where/middle-east/lebanon_en [last accessed 16 March 2020]. 
Paolo Cuttitta, "The case of the Italian Southern sea borders: cooperation across the Mediterranean?" in Gemma Pinyol (ed.), Immigration flows and the management of the EU's southern maritime border, Barcelona, Cidob Edicions, 2008, p. 45-62.

Robert Dahl, "The Concept of Power," Systems Research and Behavioral Science, 1957, Vol. 2 (3), p. 201-215.

European Commission, "Joint communication to the European Parliament, the Council, the European Economic and Social Committee and the Committee of the Regions Review of the European Neighbourhood Policy," Website, European Commission, 18 November 2015, available at: https://eur-lex.europa.eu/legal-content/en/TXT/?uri=celex:52015JC0050 [last accessed 10 February 2020].

European Union, "Supporting Syria and the Region: Post-Brussels conference financial tracking," Brussels, Relief Web, March 2019, p.4-6, available at: https://reliefweb.int/sites/reliefweb.int/files/resources/syria-report-seven_o.pdf [last accessed 10 February 2020].

Tamirace Fakhoury, "Multi-level governance and migration politics in the Arab world: the case of Syria's displacement," Journal of Ethnic and Migration Studies, 2018, p.1310-1326.

Shoshana Fine, "Bordering subjects, souls and states: an enquiry into "bordercratic" practices and rationalities in Turkey," Doctoral Dissertation, Paris, Sciences Po, 2016.

Carmen Geha and Joumana Talhouk, "From Recipients of Aid to Shapers of Policies: Conceptualizing Government - United Nations Relations during the Syrian Refugee Crisis in Lebanon," Journal of Refugee Studies, 2018, Vol. 32(4), p.645-663.

Ernst Haas, "Why Collaborate? Issue-Linkage and International Regimes," World Politics, 1980, Vol. 32 (3), p.357-405.

Ahmet Içduygu and Maissam Nimer, "The politics of return: exploring the future of Syrian refugees in Jordan, Lebanon and Turkey," Third World Quarterly, 2018, Vol. 41(3), p.415-433.

Jeanine Jalkh, “Bassil part en guerre contre le HCR,” Website, L'Orient-Le Jour, o9 June 2018, available at https://www.lorientlejour.com/article/1119987/bassil-part-en-guerre-contre-le-hcr.html [last accessed 10 February 2020].

Maja Janmyr, "UNHCR and the Syrian refugee response: negotiating status and registration in Lebanon," The International Journal of Human Rights, 2017, Vol. 2 (3), p. 393-419.

Al Jazeera, "Refugees found frozen in Lebanon near Syria border", Website, Al Jazeera News, 19 January 2018, available at: https://www.aljazeera.com/news/2018/o1/refugees-frozen-lebanon-syria-border-180119180 011632.htm [last accessed 10 February 2020]. 
Michael Kagan, "We live in a country of UNHCR: The UN surrogate state and refugee policy in the Middle East," Geneva, United Nations High Commissioner for Human Rights, 2011, available

at: https://www.unhcr.org/research/working/4d5a8cdeg/live-country-unhcr-un-surrogate-stat e-refugee-policy-middle-east-michael.html [last accessed 10 February 2020].

Robert Keohane and Joseph Nye, Power and Interdependence, London, Pearson Editions, 2001.

Dima El-Khouri, "Negotiating space: Cities in Lebanon and the challenge of the Syrian refugee influx (2011-2018): the cases of Tebbeneh, el-Nab'a, and the Bourj el-Barajneh Palestinian refugee camp," Doctoral Dissertation - Social Geography, Université de Caen, 2019.

Sandra Lavenex, "EU enlargement and the challenge of policy transfer: The case of refugee policy," Journal of Ethnic and Migration Studies, 2002, Vol. 28 (4), p. 701-72.

Lebanon Support, "Formal Informality, Brokering Mechanisms, and Illegality. The impact of the Lebanese State's Policies on Syrian Refugees' Daily Lives", Beirut, Civil Society Knowledge Centre, 2016, available at: http://civilsociety-centre.org/resource/formal-informality-brokering-mechanisms-and-illega lity-impact-lebanese-state\%E2\%80\%99s-policies [last accessed 11 February 2020].

Lebanon Support, "Syrian Refugees' Livelihoods. The Impact of Progressively Constrained Legislations and Increased Informality on Syrians' Daily Lives”, Beirut, Civil Society Knowledge Centre, 2016, available at: http://civilsociety-centre.org/resource/syrian-refugees-livelihoods-impact-progressively-con strained-legislations-and-increased [last accessed 11 February 2020].

Lebanon Support, "Access to Healthcare for Syrian Refugees. The Impact of Fragmented Service Provision on Syrians' Daily Lives," Beirut, Civil Society Knowledge Centre, 2016, p.7, available at: https://civilsociety-centre.org/sites/default/files/resources/accesshealthcaresyrianrefugees-l s2016.pdf [last accessed 10 February 2020].

The Legal Agenda, "Position Paper on the decision to summarily deport Syrian nationals who entered Lebanon irregularly," Website, The Legal Agenda, 2019, available at: https://legal-agenda.com/uploads/Position\%20Paper\%200n\%20the\%20decision\%20to\%20 summarily\%20deport\%20Syrian\%20nationals\%20who\%20entered\%20Lebanon\%20irregula rly.pdf [last accessed 10 February 2020].

Paul Light, The President's Agenda: Domestic Policy Choice from Kennedy to Clinton, Baltimore, Johns Hopkins University Press, 1982.

Annelisa Lindsay, "Surge and Selection: Power in the Refugee Resettlement Regime," Forced Migration Review, 2017, issue 54, p.11-12.

Steven Lukes, Power: A Radical View, London, MacMillan Press, 1974. 
Amreesha Jagarnathsingh, "Lebanon - Country Report: Legal and Policy Framework of Migration Governance," Working paper series 1, RESPOND: Multilevel Governance of Mass Migration in Europe and Beyond, Horizon 2020 (European Union), Civil Society Knowledge Centre, 2018, p.22, available at: https://civilsociety-centre.org/resource/legal-and-policy-framework-migration-governance [last accessed 10 March 2020].

Amreesha Jagarnathsingh, "Lebanon's Border Regime: Fluid Rigidity, Foreign Interference and Hybrid Security Assemblages," Working paper series 2, RESPOND: Multilevel Governance of Mass Migration in Europe and Beyond, Horizon 2020 (European Union), Civil Society Knowledge Centre, 2019, p.45, available at: https://civilsociety-centre.org/resource/lebanon\%E2\%80\%g9s-border-regime-fluid-rigidityforeign-interference-and-hybrid-security-assemblages [last accessed 10 February 2020].

Emmanuella Paoletti, Migration of Power and North-South Relations: The Case of Italy and Libya, London, Palgrave Macmillan, 2011.

Security Assistance Monitor, "Security Aid Pivot Table - Programs," Website, Security Assistance Monitor, 2012-2019, available at: http://securityassistance.org/data/program/military/Lebanon [last accessed 10 February 2020].

Simone Tholens, "Border management in an era of 'state building lite': security assistance and Lebanon's hybrid sovereignty," International Affairs, 2017, Vol. 93(4), p. 865-882.

Rights,

UNHCR, "Fact Sheet," Website, United Nations High Commissioner for Human https://www.unhcr.org/lb/wp-content/uploads/sites/16/2019/03/UNHCR-Lebanon-Operat ional-Fact-sheet-February-2019.pdf [last accessed 10 February 2020].

UNHCR, "Fifth Regional Survey on Syrian refugees' perceptions and intentions on return to Syria, Egypt, Iraq, Lebanon, Jordan," Website, Relief Web, March 2019, available at:

https://reliefweb.int/report/turkey/fifth-regional-survey-syrian-refugees-perceptions-and-in tentions-return-syria-rpis [last accessed 10 February 2020].

UNHCR, "Emergency Handbook," Website, United Nations High Commissioner for Refugees, 2015, p.1, available at: https://emergency.unhcr.org/entry/78614/working-with-a-host-government [last accessed 10 February 2020]. 